HURZHY VOLODYMYR, Master of Religious Studies, Junior Research Fellow, Postgraduate Department of Philosophy, Vasyl Stus Donetsk National University, Vinnytsia

\title{
RUSSIAN WORLD DOCTRINE AS RUSSIAN RESPONSE TO THE CRISIS OF THE 1990s
}

\begin{abstract}
The article explores the nature, purpose and means of influencing the public consciousness of the "Russian world" phenomenon. The origins of the project, the course of its implementation in the intellectual and power circles of Russian society are shown. It is proved that as an instrument of global competition, the "Russian world" project is an alternative to the Western project of cultural development and can be quite effective.

The author concludes that under any development of events the perspective of thinking that opens within the paradigm of the "Russian world", taking into account its relevance in modern Russia, consolidating the potential and influence on the perception and interpretation of contemporary and historical events, will remain a weighty factor in shaping Russia's policy in the coming years.
\end{abstract}

Keywords: "Russian world"; "Depreciation values"; "identity"; "geopolitics"; "Global competition"; "values"; "Soft power"; "Orthodoxy".

Formulation of the problem. Despite the fact that the issue of Russian World (RW) is being fairly debated in the Ukrainian and international media, researchers rarely focus on the nature, objectives, and RW's means of influence. What is "Russian world"? What are the consequences of this project today and what can we expect tomorrow? What does the project consist of and on what is its mobilization potential based? These issues require adequate responses.

The disintegration of the USSR, which no matter how treated, was a geopolitical shock and should be considered the essential background for developing the concept of "Russian world" in its present form. In a fairly short time, the political landscape of Europe was changed and former Soviet Republics began an independent life. Although Russia (the Russian Federation) remained the legal successor to the USSR, it could not continue its policy and had to find a certain response to the challenges caused by changes of its position in the world. Economic and social problems faced by Russia and also by all other Republics were not however of prime importance for the state. In addition to those problems and in the first place, it was necessary to do something about the thinking of people who lived in the largest and most powerful (at least from their viewpoint) state only yesterday. It was no use to hope that millions of people who believed yesterday the USA and Europe were their enemies, would suddenly become their apologists. It was also necessary to work out some foreign policy vectors and models of interaction with other states as the RF itself had changed its 'world leader' status to that of a 'regional power' in quite a short time.

Furthermore, the following question was and still is rather topical: will the democratic, purely in western terms, Russia be able to take the same place in world politics as it used to in the days of the Empire and Soviet Union? After all, the political and military might of Russia was achieved not least because of internal oppression of its own population and driving it into a tough framework. And democracy needs a politically mature and moral population, capable of making its choice and assuming responsibility for it.

In the 1990s Russia used all means for maintaining influence on the former Soviet Republics, that were moving towards independence, which resulted in a series of military conflicts in Nagorno-Karabakh, Transnistria, South Ossetia, Abkhazia, but those conflicts were not sufficiently supported by ideology, and that weakened the position of the state on the international arena. The country experienced a swift transition from socialism and planned economy to capitalism and liberal values. The values which provided the basis for world perception of the population only yesterday have ceased to exist today. It was a conceptual vacuum that developed in the domestic and foreign policy of the 1990s as well as in the heads of the Russians at the time, which needed to be filled up with something.

Analysis of recent research and publications. Discussion on "Russian world", which was conducted in Russia in the 1990s - early 2000s, was limited to searches and attempts to preserve the cultural identity of the Russian people and even find a new one instead of the lost Soviet identity. Some intellectuals of that time did not support the idea of "Americanization" of Russia, and defended its "special path". First of all, that was an opinion of the Foreign Association Analytical Group, which has been working in Moscow since 1991

Given this, we can find as rather interesting their project "Other. Reading of the new Russian identity", 1995, which was compiled by Mr. Schedrovitskii, A. Kuraiev, S. Chernyshev, V. Kahanskii, S. Kurginian, S. Kordonskii, V. Hlazychev and many others. This is a four-volume edition, the essence of which, in terms of its authors, can be summarized to the thesis of one of them: "Other is a philosophical steamer that is bound to his homeland".

The publication is based on the understanding of the fundamental challenges faced by Russia after the collapse of the Soviet Union. The organizers of the project intended to organize a certain process, to combine similar, but separate ideas, and bring them to specialists in various fields of science, and they actually succeeded in doing it. That is, the sponsors considered themselves as initiators of the conscious ideological process of post-Soviet Russia revival [1]. "The originator deeply believes that a set of ideas presented in the book 'The Other', can more than ensure the solution to the problem, which means: the revival of the country should be done first in spirit, then in the flesh." 
[2]. Although then, in the 1990s, the phrase "Russian world" did not have the modern meaning, you can clearly discern the basic ideas of the future concept in the project that is associated with a collection of "Other...".

The purpose of the article: investigate the nature, purpose and means of influencing the phenomenon of "Russian World".

Objectives of the study. The work by P. Schedrovitsky "In search of forms", that was included in this volume, should be considered as an attempt to ask which sociocultural community of people can lead Russia at the international level, and raise the issues of Russia's domestic problems to the world level. This paper provides an analysis of the USSR before its collapse and gives suggestions of what should be actually done after the collapse.

In the article "Russian world", published in 2000 in the newspaper "Independent" [lbid] these ideas were developed: the Russian language becomes the means to expand the influence of "Russian world" abroad, for "Russian world" is a community of people who speak Russian, no matter where they are physically, if spiritually they are in Russia. In fact, Russia was made beyond the physical, because, according to the author, only up to a half of all the "Russians" live in Russia; and Russia has become a cultural phenomenon, Russia is there where they speak Russian. According to P. Schedrovitsky, first of all, this gave Russia access to financial markets of the home countries of the Russian diaspora and could help attract investments to Russia itself, and "Russian world" will become a tool for the development of the global economy. But at that time these ideas were considered purely theoretical and even utopian.

Things have changed since the mid-2000s, when "Russian world" gradually moved from intellectual circles to the Kremlin government offices and the Russian Orthodox Church, becoming one of the main vectors of the Russian foreign policy. This is particularly due to a high attractiveness and high mobilization potential of the concept. And it is also due to the fact that many members of the "Other" began to take rather high political and scientific positions, such as S. Kordonsky, the Chief Executive of the Expert Department of the Presidential Administration of the Russian Federation in 2000-2004, a Senior Assistant of the President of Russia in 2004-2005, a valid state adviser of the Russian Federation of the $1^{\text {st }}$ class. P. Shchedrovitsky is currently a Deputy Director of the Institute of Philosophy of the RAS. V. Glazychev is a Doctor of Philosophy, Doctor of Arts, Professor of the Moscow Architectural Institute, a member of the Russian Federation Public Chamber.

Since 2004, Russian ideologues have begun to actualize those basic values with which it is possible to carry on foreign policy and hope to win in the global competition of nations. Protecting the interests of the Russianspeaking, Orthodox population was a perfect fit for that. Taking into account that the ethnic Russians live compactly in former Soviet Republics, it was decided to rely on the diaspora. In 2004, the former Minister of Foreign Affairs Mr. Ivanov said, addressing the VIII World Russian People Congress: "... We cannot but consider the fate of the Orthodox world out of the global context and the most important and long-term objectives of our foreign policy are now being solved", "... and of paramount importance here are the CIS countries. The Commonwealth with its borders almost coincides with the canonical territory of the Moscow Patriarchate ... Against the background of the collapse of the many pre-existing relations, a religious factor retains its unifying and integrating value" [4].
In the late 2006, Russian President Vladimir Putin said at a meeting with the intellectuals: "Russian world can and should unite all who cherish Russian word and Russian culture, wherever they live, in Russia or abroad. Use this phrase more often- 'Russian world'" [5] ... Later, in 2007, the Russian World Fund was created by Presidential Decree Number 796 [6], which is aimed to make Russian language and culture popular in Russia and in the world. In 2014 under the auspices of the Fund, there were 100 "Russian Centers" working in 45 countries and 145 "Russian World Studies" in 56 countries. The objectives of the Fund were articulated more clearly. "Russian World has changed over the last year, it was changed by Ukraine. Seven years ago we talked about Russian World as a cultural phenomenon, we talked about the world of Russian language and culture. Now, increasingly politicized Russian world is becoming more political than a cultural category", the Fund Executive Director Mr. Vladimir Kochin said [7]

In 2006, Vladislav Surkov, who was at that time considered the chief ideologist of the Kremlin expressed his opinion in the article "The nationalization of the future" [8]. It's quite revealing that the article was presented at the Institute of Philosophy of the RAS. He noted that Russia is a part of Europe, but a specific part with a specific type of democracy and its unique way of development, with its history, no matter how horrible sometimes it was, but it is the history that enables the Russians to understand themselves and their civilizational role in the global world. Denying its history, for example, having condemned the crimes of the Soviet Union or the history of the imperial period, Russia simultaneously denies the formation of the "Third Rome", the time when it conquered space, when geopolitically the USSR occupied a key position in the world, and above all the time when a victory was won in World war II, and all the territories that have been lost due to the collapse of the USSR, were yet a single entity. That means that the key fundamental events for understanding itself as a superpower and the media of a "special path" exist no longer, and existential Russia itself ceases to exist. So these statements are philosophical axioms that must be protected to the end because their loss is death. That offers quite a serious mobilization potential.

Democratic changes in Russia set in owing to the European essence of Russian culture rather than as a consequence of a failure in the "cold war", as a matter of fact, according to V. Surkov, there was no failure. But it still remains to develop a support mechanism for its own sovereignty without detriment to democracy and to stay open without loss of its own identity. The sovereignty itself has to become a civil value for the purpose whereas no real democracy is possible without civil solidarity. Formal attributes of democracy do not suffice in this case, it is necessary to take into account civilizational mechanisms of peoples in a certain territory.

The President of the RF Mr. V. Putin also agreed with these statements when maintaining his view in conversations with key politicians of the world: "Do not paralogize, - he said to the Vice-President of the USA Mr. Joe Biden sometime during negotiations, - we are absolutely unlike you. We only resemble you. But we are entirely different. It is only by sight that the Russians are no different from the Americans. In fact, our internal arrangement is different. We have utterly different values" [9].

"Just fancy, here you are seated in the Kremlin, - he said to Mrs. Angela Merkel, - and you have voters living in Kaliningrad and some living in Petropavlovsk-Kamchatsk. And you have to somehow unite this entire territory, different in languages, views and ways of life. You have to tell to 
these people something which would stick them together. One of your countrywomen, a great countrywoman, was our Empress Catherine II. At first, she intended to quickly abolish serfdom. But then she learnt how Russia was structured and I'll tell you what she did. She strengthened the nobility rights and destroyed the peasantry rights. In our country it is impossible to act differently: a step to the right, a step to the left - and that's it, you are losing power" [lbid, p.306].

The vision and value potential of "Russian world" can be used for mobilization of anti-Western movements, offering them a basis for theoretical justification of their own views and non-utilitarian development guidelines. After the appeal of V. Putin to Russian intelligentsia for "more often use of the word combination "Russian world" (2006) and the opening of the Russian World Fund (2007), it is the rhetoric which is changing at first and then actually the RF foreign policy.

In the summer of 2008, almost simultaneously, two events happened - the armed conflict started in South Ossetia, with Russia and Georgia being involved, and one of the ideologists of the new foreign policy paradigm, Sergei Lavrov, presented his program article "Russia and the World in the 21st century" [10]. It includes, inter alia, a kind of ideological and axiological manifesto justifying a new vision: "There is no doubt that after the Cold War had come to an end, the stage of world development, which lasted for 400-500 years and in which the European civilization was dominant in the world, ended to... The West. There are two basic approaches to assessing what this stage of human development means. According to the first one, the world has to gradually become the Big West through the adoption of Western values. This is a unique version of the 'end of history'. The second approach which we support is that competition becomes global in nature and civilization dimension. It means that the subject of competition includes also value orientations and development models." [lbid].

Moscow's changing the point of view on the world events gradually led to significant changes not only in the rhetoric but also in the thinking of Russian leaders that Igor Zavelov described as follows: "In Russia, there appeared a new foreign policy doctrine based on a set of ideas about the uniqueness of Russian civilization, the Russian World and the need to protect compatriots, using power ways as well." [11].

During one of his visits to Ukraine in July 2009, Patriarch Cyril said, making a speech in St. Nicholas's Cathedral of Gorlovka city: "Here, on the holy land of the Donbas, I cannot but tell about the relations between Russia and Ukraine. This is a common space of Holy Rus, including Belarus and many other countries. We are a single people having emerged from the laver of Kiev christening. There are differences in languages, customs, spirits but we live, adhering to the same values. And while there exist common values, there is also this spiritual commonality. And if there is spiritual commonality, there should also be solidarity and mutual support, including during the hard times of the economic depression" [12].

The religious motive is important for "Russian world" in the historical sense: "The core of Russian world is now Russia, Ukraine, Belarus, and Saint Reverend Laurentius of Chernigiv expressed this idea with a well-known phrase: 'Russia, Ukraine and Belarus are what we mean by the Holy Rus.' It is this understanding of Russian world that is represented in the modern name of our Church. The Church is called Russian not by ethnicity. The name indicates that the Russian Orthodox Church takes up a pastoral mission among the nations which consider Rus spiritual and cultural tradition as the basis of their own national identity, or as its essential part. That is why we believe that Moldova is a part of Russian world" [13] - these words convey the Moscow Patriarch's view of at least the territories of "Russian world".

"Russian world" rests on "honoring the dates, places, monuments and names associated with the most important and critical pages of civil history of peoples". It is understandable that it is this cultural space to be perceived as a "spiritual tradition" created by the Orthodox Autocephalous Church, which is an "invaluable resource" during the globalization age.

Saying this, the Head of the Russian Orthodox Church continued another post-Soviet tradition and, actually, repeated verbatim the words of Alexander Solzhenitsyn, who believed that post-Soviet Russia, Ukraine and Byelorussia had to create a unified cultural and political space "Rebuilding Russia" [14]: "I do not anticipate here the role and place of the current Supreme Council of Russia, Ukraine and Belarus, but it is natural to suggest that at the end of the next term provincial local assemblies should delegate their representatives to the House of the Union (replacing the Union Council), the General Assembly (replacing the Supreme Council of Deputies ), while they themselves should be re-elected by local assemblies on the same principles."

\section{Conclusions}

The vision and value potential of "Russian world" can be used to mobilize anti-Western movements, giving them a basis for theoretical justification of their own beliefs and non-utilitarian guidelines. Currently, the dominant point of view in Russia is that following the Western model of development is not justified, and implementation of its values does not ensure a sustainable development of the country, as many Western values may change in the coming years. In their studies, Russian scholars and ideologues came to the conclusion that Russia has its own history, and, no matter how horrible it was sometimes, but it is the history that enables the Russians to understand themselves and their civilizational role in the global world.

The concept of "Russian world", which, in one form or another, for centuries have played the role of Moscow and the Russian state's identity in its relations with the West, has taken a new form now. Revived after the devaluation of the communist ideology, the ideologeme became a tool of competitive racing in the global game.

Whether this project in its new reincarnation was conceived as a weapon of ideological and simply wars (certain proofs in favor of this thesis are given above), whether it has matured as a means of preservation of the Russian identity and culture, but today it has turned into an effective religiously motivated alternative of that global development project which was developed by the West.

We can be sure to expect that under any scenario the prospect of thinking which opens within the paradigm of "Russian world", given the modern Russia's demand for consolidating resources and its impact on the perception of modern and interpretation of historical events, will remain an important factor in Russia's policy making in the coming years.

\section{REFERENCES}

1. Gurzhy, V.S. (2015), Consequences to Implement the Doctrine "Russky Mir" in Ukraine, Skhid, № 2, 34-40. DOI: 10.21847/ 1728-9343.2015.2(134).40085

2. Chernyshev, S. (1997), The apology of the compiler, available at: http://old.russ.ru/antolog/inoe/ (rus).

3. Shedrovitsky, P.G. (2000), Russian world, Niezavisimaya gazeta, 02.11, available at: http://www.ng.ru/ideas/2000-02-11/ 8_russian_world.html (rus) 
4. Ivanov Igor (2006), Speech by the Minister of Foreign Affairs of the Russian Federation at the VIII World Russian People's Council, available at: https://mospat.ru/archive/page/church-and-society/ 30422.html (rus)

5. We will build Russian world! (2006), Litieraturnaya gazeta, available at: http://old.lgz.ru/archives/html_arch/lg492006/Polosy/ 1 1.htm

6. Order of the president of the Russian Federation (2007), Establishment of the fund "Russian World", available at: http:// russkiymir.ru/fund/the-decree-of-the-president-of-the-russianfederation-on-creation-of-fund-russian-world.php

7. Kochin, Vladimir (2014), Russian World's attraction, Strategy of Russia. The publication of the Unity for Russia Foundation, available at: http://sr.fondedin.ru/new/fullnews.php?subaction =showfull\&id=1409560529\&archive=1409042400\&start_from=\&ucat=14\&

8. Surkov, V. (2006), Nationalization of the Future, Expert № 43 (537). November 20, available at: http://expert.ru/expert/2006/ 43/nacionalizaciya_buduschego/
9. Zygar, Mikhail (2016), The whole Kremlin's army: A Brief History of Modern Russia, Intellectual Literature, Moscow, 408 p. (rus).

10. Lavrov, S.V. (2008), Russia and the World in the XXI century, Russia in Global Affairs, № 4, available at: http://www.globalaffairs.ru / number / n 11159

11. Zavelev, I.A. (2014), The transformation of national identity and a new foreign policy doctrine of Russia, Russia in Global Affairs, № 2, available at: http://www.globalaffairs.ru/number/ Granitcy-russkogo-mira--16582.

12. The Word of His Holiness Patriarch Kirill in the St. Nicholas Cathedral in Gorlovka (2009), available at: http://www.patriarchia. $\mathrm{ru} / \mathrm{db} / \mathrm{text} / 707934 . \mathrm{html}$

13. Speech by His Holiness Patriarch Cyril at the official opening of the 3d Assembly of Russian World available at: http:// www.patriarchia.ru/db/text/928446.html.

14. Solzhenitsyn, A. (2008), Rebuilding Russia, Komsomolskaya Pravda, August,5, available at: http://www.msk.kp.ru/daily/ $24141 / 359116 /$

Гуржи Владимир,

магистр религиоведения, младиий научный сотрудник, аспирант кафедры философии, Донецкий национальный университет имени Василия Стуса, г. Винница

\section{ДОКТРИНА "РУССКОГО МИРА" КАК ОТВЕТ РОССИИ НА КРИЗИС 1990-Х}

В статье исследуется характер, цели и средства воздействия на общественное сознание феномена "русский мир". Показаны истоки проекта, ход его внедрения в интеллектуальных и властных кругах российского общества. Доказано, что в качестве инструмента глобальной конкуренции, проект "русского мира" является альтернативой западному проекту культурного развития и может быть достаточно эффективным.

Автор делает вывод, что при любом развитии событий открывающаяся в пределах парадигмы "русского мира" перспектива мышления, учитывая ее востребованность в современной России, консолидирующий потенциал и влияние на восприятие и интерпретацию современных и исторических событий, будет оставаться весомым фактором формирования политики России в ближайшие годы.

Ключевые слова: "русский мир"; "девальвация ценностей"; "идентичность"; "геополитика"; "глобальная конкуренция"; "ценности"; "мягкая сила"; "православие".

Гуржи Володимир,

магістр релігієзнавства, молодший науковий співробітник, аспірант кафедри філософії,

Донецький національний університет імені Василя Стуса, м. Вінниия

\section{ДОКТРИНА "РУССКОГО МІРА" ЯК ВІДПОВІДЬ РОСІї НА КРИЗУ 1990-х}

У статті автор досліджує характер, цілі і засоби впливу феномену "рускій мір". Що це таке? Якими є наслідки цього проекту сьогодні й на що ми можемо очікувати завтра? У чому суть проекту й на чому засновано його мобілізаційний потенціал? Такими є основні питання дослідження.

Показано, що проект виник у результаті пошуку Росією відповіді на виклики, пов'язані зі зміною власного становища у світі (через розпад СРСР, зміну політичного ландшафту Європи й політичного курсу самої РФ). У 1990-ті роки Росія будь-яким чином намагалася зберегти вплив на колишні радянські республіки, які стали на шлях незалежності. Це вилилось у ряд військових конфліктів, проте вони не були достатньо ідеологічно опрацьовані, що призвело до втрати і без того не виразного міжнародного авторитету держави.

На думку автора, якщо дискусію про "русскій мір", яка велась у Росії, у 1990-х - початку 2000-х років, можна звести до пошуків і спроб зберегти культурну ідентичність російського народу, або навіть віднайти нову, навзаєм втраченої радянської, то з середини 2000-х років, коли проект перейшов 3 інтелектуальних кіл до владних кабінетів Кремля, він стає одним з основних векторів у зовнішній політиці Росії.

Доведено, що в першу чергу це пов'язано з високою привабливістю і великим мобілізаційним потенціалом даної концепції. У якості інструмента глобальної конкуренції, проект "русского міра" є очевидною альтернативою західному проекту культурного розвитку та може бути досить ефективним.

Автор робить висновок, що за будь-якого розвитку подій, та перспектива мислення, що відкривається в межах парадигми "русского міра" - враховуючи її затребуваний у сучасній Росії консолідуючий ресурс й вплив на сприйняття сучасних та інтерпретацію історичних подій - буде залишатися вагомим фактором у формуванні політики Росії в найближчі роки.

Ключові слова: "русскій мір"; "девальвація цінностей"; "ідентичність"; "геополітика"; "глобальна конкуренція"; "цінності"; "м'яка сила"; "православ'я".

(C) Гуржи Володимир

Надійшла до редакції 03.02.2017

СХІД № 1 (147) січень-лютий 2017 р. 